\title{
Research Agenda for Library Instruction and Information Literacy
}

Melissa Becher

Jean Caspers

Linfield College

Follow this and additional works at: https://digitalcommons.linfield.edu/librariesfac_pubs

Part of the Library and Information Science Commons

\section{DigitalCommons@Linfield Citation}

Becher, Melissa and Caspers, Jean, "Research Agenda for Library Instruction and Information Literacy" (2003). Faculty \& Staff Publications. Published Version. Submission 6.

https://digitalcommons.linfield.edu/librariesfac_pubs/6

This Published Version is protected by copyright and/or related rights. It is brought to you for free via open access, courtesy of DigitalCommons@Linfield, with permission from the rights-holder(s). Your use of this Published Version must comply with the Terms of Use for material posted in DigitalCommons@Linfield, or with other stated terms (such as a Creative Commons license) indicated in the record and/or on the work itself. For more information, or if you have questions about permitted uses, please contact digitalcommons@linfield.edu. 


\section{Guest Editorial}

\section{Research Agenda for Library Instruction and Information Literacy}

In 1980, the Research Committee of the ACRL Bibliographic Instruction Section published a groundbreaking document in CERL News called the Research Agenda for Bibliographic Instruction. This research agenda sought to add new depth to an existing body of research related to teaching, including instructional media and pedagogical methodology. It posed new questions covering topics such as determining institutional needs for instruction, measuring library skill levels of students, effectively managing bibliographic instruction programs, and determining the impact of library instruction within and outside the library. The document also called for new research in these emerging areas to provide tools and methods for determining the effectiveness of instruction programs.

Twenty years later, the ACRL Instruction Section's Research and Scholarship Committee took on the project of updat ing the 1980 research agenda. The committee found that although the questions posed in 1980 were still relevant, driving forces such as the diversification of user populations, increased focus on assessment and institutional outcomes, increasingly networked campuses, and changes in expectations for the academic library and the librarian's role in higher education added new dimensions to the instructional environment. The concept of information literacy, now a major focus of effort, had not been present in 1980 . Over the course of two years, the $\mathrm{Re}$ search and Scholarship Committee reviewed the scope of existing research in the field and identified important areas needing research attention. Information literacy was given prominence in the new document to reflect its central place in our current theory and practice. Questions were devised not as actual research questions but, rather, to spark ideas for new research among practitioners, scholars, and students.

The resulting new Research Agenda for Library Instruction and Information Literacy is organized into four sections entitled "Learners," "Teaching," "Organizational Context," and "Assessment." Questions under the "Learners" section address changing audiences for library instruction, learning styles, and skills needed to use information effectively, particularly in the online environment. The "Teaching" section covers pedagogy, instructional design and scalability, methods of instruction, and continuing education for the librarian instructor. The "Organizational Context" section questions treat the library instruction program in relation to the library's organizational structure, the larger institutional environment, and the university's faculty. The "Assessment" section questions address the evaluation of instructors, the assessment of learning outcomes, and the transferability of information literacy skills from class to class and from higher education to the workplace and life situations.

The new research agenda was published in CERL News in February 2003 and introduced to the library community through a program at the ACRL National Conference in April 2003. Initial response 28 ference attendees was quite positive. From the evaluation forms collected, 94 percent of the people attending the session responded that they agreed or somewhat agreed with statements such as: "The Research Agenda for Library Instruction and Information Literacy frames important questions currently facing library instructors," and "I would recommend use of the Agenda to other librarians." Many comments described the research agenda as "ambitious" and moving library instruction in a needed direction. A significant number felt that the research agenda was a starting point for facilitating research, and that the Research and Scholarship Committee could develop related tools to use with it. Of particular interest was a database where researchers could identify others who shared their interests.

Promulgation of the research agenda to the library community beyond the ACRL Instruction Section is a major thrust for the committee in the immediate future. The committee plans to initiate publications and programs and to advocate inclusion of the research agenda in discussions at teaching workshops, in library and information science programs, and within other ALA committees also working in support of scholarship by librarians.

The committee's review and analysis of the literature resulted in a core bibliography of representative publications in the field. The committee's intention is to create a living document, continuously refreshed by gathering and categorizing new citations as an ongoing project to revise the research agenda within a projected five-year time frame. Between revisions, the bibliography will be main- tained and updated on the committee's Web site.

We encourage you to take a look at the research agenda, either in CERL News (vol. 64, no. 2, pp. 108-13) or on our Web site, shown below. This document may be useful:

- as a springboard for ideas about subject areas in which you might publish

- to reframe current projects you may be involved in at your institution into the subject of a researched article for publication;

- to help explain to faculty and/or administrators at your institution how the role of the librarian is changing and the current instructional issues facing academic librarians;

- as a tool for professional development, including mentoring programs

- in discussions with colleagues at your own and other institutions to identify common research interests and the potential for collaboration.

The ACRL Instruction Section's Research and Scholarship Committee is interested in hearing your comments about the research agenda and related programs or projects that might facilitate your instruction-related research. Please contact Jean Caspers at jcaspers@linfield.edu.

Melissa Becher and Jean Caspers Outgoing and Incoming Chairs, ACRL IS Research and Scholarship Committee

Link to the research agenda on the committee's Web site: http:/ www.ala.org/Content/ ContentGroups/ACRL1/IS/ ISCommittees/Web_pages/Research/ Research_Agenda_for_Library_ Instruction_and_Information_Literacy.htm. 